\title{
Analysis of Factors Which Affecting the Economic Growth
}

\author{
Suparna Wijaya \\ Direktorat Jendral Pajak \\ E-mail: suparnawijaya68@gmail.com
}

Received: September 6, 2016; Accepted: January 9, 2016; Published: March 2, 2017

Permalink/DOI: http://dx.doi.org/10.17977/um002v9i12017p076

\begin{abstract}
High economic growth and sustainable process are main conditions for sustainability of economic country development. They also become measures of the success of the country's economy. Factors which tested in this study are economic and non-economic factors which impacting economic development. This study has a goal to explain the factors that influence on macroeconomic Indonesia. It used linear regression modeling approach. The analysis result showed that Tax Amnesty, Exchange Rate, Inflation, and interest rate, they jointly can bring effect which amounted to $77.6 \%$ on economic growth whereas the remaining $22.4 \%$ is the influenced by other variables which not observed in this study.
\end{abstract}

Keywords: tax amnesty, exchange rates, inflation, SBI and economic growth JEL Classification: $\mathrm{O} 23, \mathrm{O} 40$

\section{INTRODUCTION}

High economic growth and sustainable process have become important measure of the economic growth in Indonesia. As demographic population has increased, it is followed by the economy needs and country's economic achievements which impact the economic growth (Cypher \& Dietz, 2008). They are together increase national aggregate output (goods and services) which socalled GDP at current prices every year. By looking at the macroeconomic and fiscal analysis result, the overall economic performance in the current year can be described and estimated (Korajczyk \& Levy, 2003). So in terms of macroeconomics, the economic performance sometimes represented by the GDP at current prices and how government launching their public policy which impacting the government capability to handle the economic growth in the country.

However, there are other non-economic indicators which also important such as indicators of public policy, government capability to handle social and political factors, law, and relations policy with foreign countries. They are must be revealed to understand the macroeconomic behavior of a country and its prospects.

In this study, the economic growth is evaluated from the public policy approach especially from the government recent policy of tax reform and tax amnesty (Bird \& de Jantscher, 1992). As budgeting is important instrument for the government to handle economic development, the government sometimes optimizes the revenues in the tax sector. There are various efforts which have been launched by the government of Indonesia such as Tax Reform Act 
(improvement of Tax Law) which become effective since 1983 till the end of 2009. As the change in the taxation paradigm and rapid economic development, the taxation law is no longer suitable with the recent socioeconomic Indonesia (Chua, 1998). Since 2009, Indonesia has adopting the use of tax ratio and tax revenue as measures of economic performance.

Both policies have bring impacts on the national as well as mutual cooperation with international which bring higher development as tax payer increase their contribution in generating public revenues (Di John, 2006). Contrarily, the use of tax ratio as a measure of performance of tax revenues also debated because it is contradicted by other economic facts and data Dagan (1999) questioned the tax revenues which considered over-rated and associated with a lower economic growth. It can be traced back to previous years of fact that during the New Order, Indonesia implemented a tax ratio of 7.4 percent and gained 6.1 percent economic growth rate. It was contradicted in Reform era of Abdurrahman Wahid which launched tax ratio of 10.7 percent but economic growth rate fell to 4.8 percent which continued in Megawati administration where tax ratio reached 13.5 percent and resulted economic growth rate of 4.2 percent. In the article of Sunarsip "Mega Facts and Mega Illusion" as reported by Republika 8th September 2004, the taxation figures can contain biased number because it does not consider aspects of inflation.

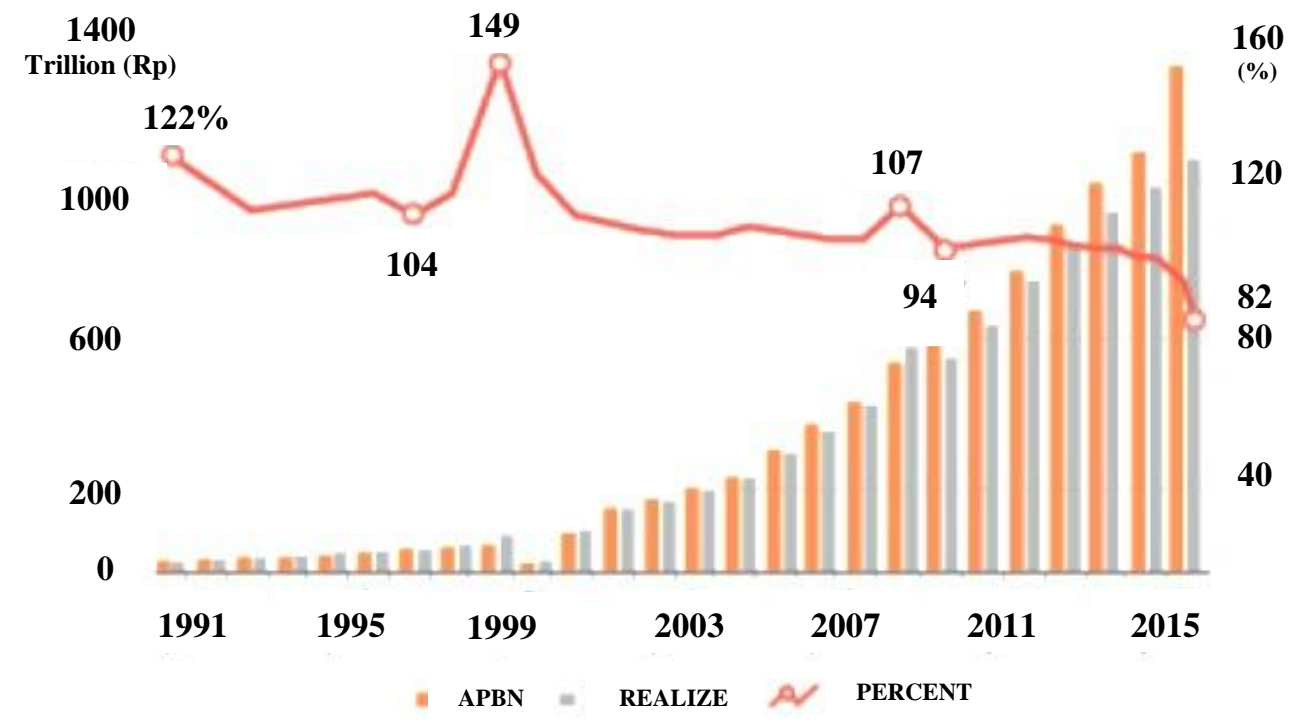

Figure 1. Tax realization since 1991

(Source: BPS, 2016)

Such symptoms still continue till 2015. As projected budget which

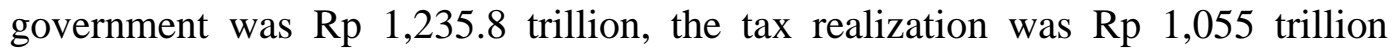
(including customs). The amount was equivalent to 83 percent of the target in the revised budget-2015. Such deficit also happened to the further year of 2016. The budget deficit in 2016 amounted to Rp 318.5 trillion, or 2.8 percent of the Gross Domestic Product (GDP). The realization was higher than the predicted budget deficit in APBN-P-2015 which pegged at 1.9 percent of GDP. 


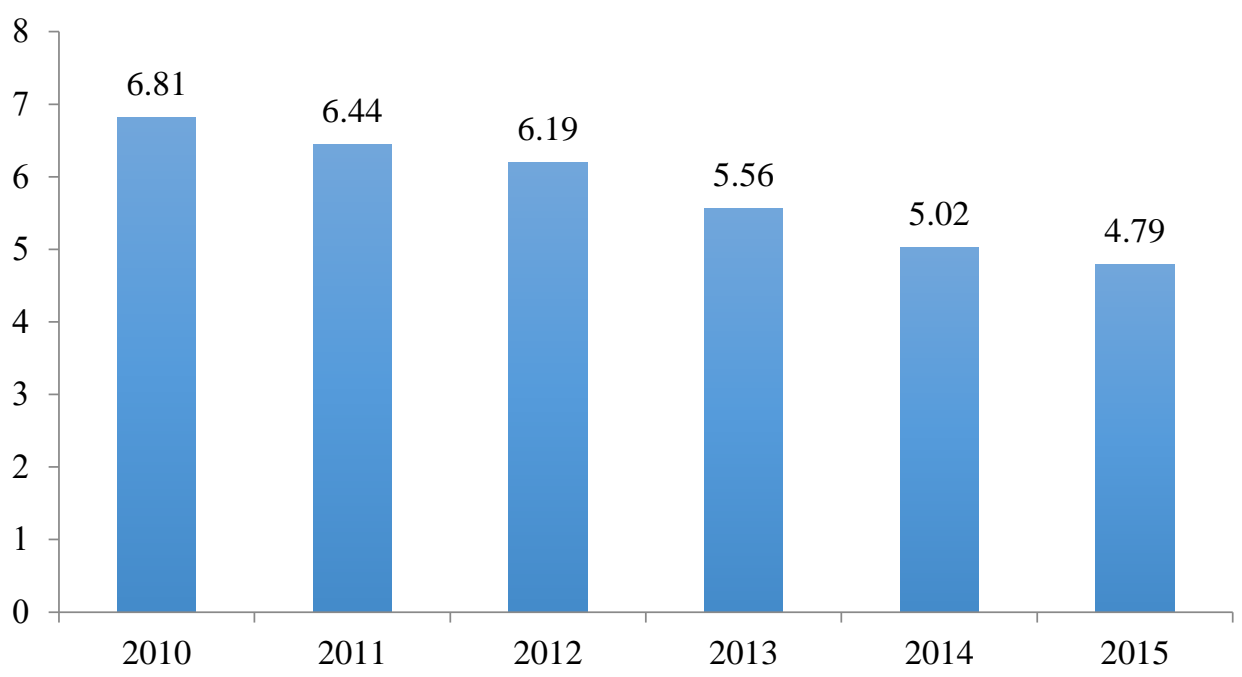

Figure 2. Indonesian Economic Growth 2010-2015

(Source: BPS, 2016)

The slowdown led to the decline of tax revenue and has also reduced the availability of budget liquidity to boost economic growth. As reported by Bappenas, historically, the tax revenues in 2010 has increased $14.3 \%$ from a year earlier and still increased higher in 2011 of $17.2 \%$. However, in two consecutive years of 2012 and 2013, it reduced to 8.9 and $6.1 \%$. Whereas, in 2014, 2015, and 2016 there was an increase in new tax revenue with average of $22.9 \%$ compared than the previous years. The rapid increase of tax revenue in 2015 and 2016 are caused by the government offer of tax amnesty policy.

Table 1. National Revenue Realization (in Billion Rupiah) 2007-2016

\begin{tabular}{|c|c|c|c|c|c|c|c|}
\hline $\begin{array}{l}\text { Sources of } \\
\text { Acceptance }\end{array}$ & 2010 & 2011 & 2012 & 2013 & 2014 & 2015 & 2016 \\
\hline Domestic & 992 & 1205 & 1332 & 1432 & 1545 & 1496 & 1784 \\
\hline Revenues & 249,00 & $\mathbf{3 4 6 , 0 0}$ & 322,90 & 058,60 & 456,30 & 047,33 & 249,90 \\
\hline Tax Revenues & $\begin{array}{r}723 \\
30700\end{array}$ & 873874,00 & 980518,10 & $\begin{array}{r}1077 \\
30670\end{array}$ & $\begin{array}{r}1146 \\
86580\end{array}$ & $\begin{array}{r}1240 \\
41886\end{array}$ & $\begin{array}{r}1539 \\
16620\end{array}$ \\
\hline Domestic Tax & 694 & & & 1029 & 1103 & 1205 & 1503 \\
\hline & 392,00 & 819752,00 & 930861,80 & 850,00 & 217,60 & 478,89 & 294,70 \\
\hline Income tax & $\begin{array}{r}357 \\
045,00\end{array}$ & 431122,00 & 465069,60 & 506442,80 & $\begin{array}{r}546 \\
180,90\end{array}$ & 602308,13 & $\begin{array}{r}855 \\
842,70\end{array}$ \\
\hline value-added tax & $\begin{array}{r}230 \\
605,00\end{array}$ & 277800,00 & 337584,60 & 384713,50 & $\begin{array}{r}409 \\
181,60\end{array}$ & 423710,82 & $\begin{array}{r}474 \\
235,30\end{array}$ \\
\hline property tax & 28581,00 & 29893,00 & 28968,90 & 25304,60 & 23476,20 & 29250,05 & 17710,60 \\
\hline $\begin{array}{l}\text { Bea on Acquisition of } \\
\text { Land and Buildings }\end{array}$ & 8026 & -1 & 0 & 0 & 0 & 0 & 0 \\
\hline Tax & 66166,00 & 77010,00 & 95027,90 & 108452,00 & $\begin{array}{r}118 \\
085,50\end{array}$ & 144641,30 & $\begin{array}{r}148 \\
091,20\end{array}$ \\
\hline Other Taxes & 3969,00 & 3928,00 & 4210,90 & 4937,10 & 6293,40 & 5568,30 & 7414,90 \\
\hline The International Trade Tax & 28915,00 & 54122,00 & 49656,30 & 47456,60 & 43648,10 & 34939,97 & 35871,50 \\
\hline Import duty & 20017,00 & 25266,00 & 28418,40 & 31621,30 & 32319,10 & 31212,82 & 33371,50 \\
\hline Export tax & 8898,00 & 28856,00 & 21237,90 & 15835,40 & 11329,00 & 3727,15 & 2500,00 \\
\hline Non Tax Revenues & $\begin{array}{r}268 \\
942,00\end{array}$ & 331472,00 & 351804,70 & 354751,90 & $\begin{array}{r}398 \\
590,50\end{array}$ & 255628,48 & $\begin{array}{r}245 \\
083,60\end{array}$ \\
\hline $\begin{array}{l}\text { Reception of Natural } \\
\text { Resources }\end{array}$ & $\begin{array}{r}168 \\
825,00\end{array}$ & 213823,00 & 225844,00 & 226406,20 & $\begin{array}{r}240 \\
848,30\end{array}$ & 100971,87 & 90524,30 \\
\hline SOE profits & 30097,00 & 28184,00 & 30798,00 & 34025,60 & 40314,40 & 37643,72 & 34164,00 \\
\hline $\begin{array}{l}\text { Other Non Tax } \\
\text { Revenues }\end{array}$ & 59429,00 & 69361,00 & 73458,50 & 69671,90 & 87746,80 & 81697,43 & 84124,00 \\
\hline $\begin{array}{l}\text { Revenue of Public } \\
\text { Service Agency }\end{array}$ & 10591,00 & 20104,00 & 21704,30 & 24648,20 & 29681,00 & 35315,46 & 36271,20 \\
\hline Grant & 3023,00 & 5253,90 & 5786,70 & 6832,50 & 5034,50 & 11973,04 & 1975,20 \\
\hline Total & $\begin{array}{r}995 \\
271,50 \\
\end{array}$ & $\begin{array}{r}1210 \\
599,70 \\
\end{array}$ & \begin{tabular}{r|}
1338 \\
109,60 \\
\end{tabular} & $\begin{array}{r}1438 \\
891,10 \\
\end{array}$ & $\begin{array}{r}1550 \\
490,80 \\
\end{array}$ & $\begin{array}{r}1508 \\
020,37 \\
\end{array}$ & $\begin{array}{r}1786 \\
225,00 \\
\end{array}$ \\
\hline
\end{tabular}

Source: Bank Indonesia, 2016 
The tax amnesty policy has become new trend of taxation strategy implemented by Indonesia in order to attract capital owner to enlist and move their assets and treasures into Indonesia (Dodds, 2012). Through tax amnesty policy, there are many treasures of Indonesian citizens who are placed outside Indonesian territory are liquidated and send back to the country. The policy also boosts liquidity of capital to promote national economic growth. Such tax amnesty can be an instrument in the determination of the tax revenue target (Bird,1989). The policy also becomes government's instrument to manage the state budget which directly has impact on inflation and interest rate.

Jointly, the variables are assumed to have enough influence on economic growth. Since tax amnesty focused on the income tax revenue, it impacted directly to the activities of the business industry. The implications of changes in these variables will affect the prices of goods and services and the national income and expenses as recorded by the taxpayer and for-profit entities. It is similar to the rate hike triggered by rising interest rates which leading to increased operating expenses.

Another factor impacted the economic growth in Indonesia is the difference in currency exchange rates. Exchange rate is an amount of domestic money needed in rupiah to obtain one unit of foreign currency (Flood \& Garber, 1984). The exchange rate is important variable in an open economy which impact other variables such as price, interest rate, balance of payments and current account (Kouri, 1976). Based on the above background, this paper wants to examine tax amnesty and economic growth and how both variables can influence into Indonesian macroeconomic.

\section{LITERATURE REVIEW}

\section{Taxes}

Tax is a levy to the state (which can be imposed) that are owed by the mandatory pay regulated by government in order to finance public expenditures related to national budgeting (Gelfand,1978). Meanwhile, argued that taxes are people dues to the state as transition wealth from the private sector to the public sector under laws which can be enforced by not obtaining the benefits directly to be given which used as a booster, resistor or a deterrent to achieve the objectives in the field of public finance. Furthermore Lefcoe (2011) explained that tax is a state obligation and citizen's dedication to finance various public purposes, either in the form of national development as stipulated in certain Acts and regulations for the purpose of state welfare. From the definition of taxes, it can be combined that tax is the duty of citizens in national development in financing efforts which imposed without reward for his achievements (Steinmo,1996).

\section{Exchange Rate}

The exchange rate is the ratio of value or price of a currency with another currency. Each country has its own instrument of exchange rate which determines the value of a currency with other currency. The exchange rate consists of the nominal value with other country's currency. Foreign exchange rates will vary depending on the dynamics of demand and supply of foreign exchange. As exchange rate is required in foreign transactions of international payments, the exchange rate can fluctuate and bring a risk of difficulties in the business 
community especially in export-import markets (Engel, 2013). Therefore, the management of the currency into stable condition is important through monetary support (Smets, 2013).

The decline in the rupiah exchange rate against foreign currencies, especially the US dollar had a negative effect on the economy and capital markets. If the exchange rate depreciates, the value of domestic currency decline means that the foreign currency exchange rate is the exchange rate getting higher (price), it will cause exports to rise, so that rising exports will push economic growth. If the value of the dollar exchange rate increases, the volume of exports will also increase (Chaney, 2016).

\section{Interest Rate of Bank Indonesia Certificates (SBI)}

SBI interest rate has been long used as a reference for commercial banks in determining the level of deposit rates. It is the instrument of monetary policy that implemented on monetary operations conducted by Bank Indonesia as liquidity management tool to achieve monetary target. Bank Indonesia interest rate or so-called Bank Indonesia Certificates is issued as government infrastructure to influence domestic investment. Such investments include investments in state bonds and deposits.

\section{Investment Level}

According to Jackson \& Smith (2014) Inflation is a trend of rising prices in lack of supply and enormous demand which occurred continuously. This does not mean that various price of goods rose at the same time with similar percentage. The increased inflation rate happened just once which not caused by supply-and-demand but also the inflation policy implemented by government. Inflation is also the tendency of prices to rise due to the mismatch of government policy with the market situation.

\section{Economic Growth}

According Lewis (2013) economic growth is defined as an increase in the ability of a country to produce goods and service. Coale \& Hoover (2015) Stated the growth can be fluctuated depending on the level of achieved economic production which can be compared from near future year with the previous year. The comparison result showed the production value in certain period which socalled Gross Domestic product (GDP).

Gross Domestic Product (GDP) is the value of the entire production value of goods and services produced by a variety of economic activities in a region within a certain period, usually every year (Costanza et al., 2014) GDP measures the market value of final goods and services produced by resources that are within a country during a certain period, usually one year. GDP is often used as benchmark to determine the development of a country and can be compared from one country to another to convert them into a common currency (Gourinchas \& Jeanne, 2013)

\section{METHOD}

This study used linear regression modeling approach. The variables used in this study is the independent variable by using the variable tax amnesty (x1), 
exchange rates (x2), inflation (x3) and SBI (x4). Meanwhile, the dependent variable is economic growth in Indonesia $(Y)$. This study also used secondary data in the form of time series record. The time series data consisted of data row of the timed record which collected over a period/specified period of time.

The time series data were downloaded from the website of Bank Indonesia (www.bi.go.id) as regulator and state institution with the main task to maintain stability in the rupiah currency. The population used was the whole time series data consisted of quarterly inflation rates, interest rates SBI, economic growth and the rupiah during the period 2011-2015. Furthermore, the data were analyzed using regression analysis contained in E-views program 4.1 with Ordinary Least Squares (OLS).

\section{RESULT AND DISCUSSION}

The results of multiple regression analysis in Table 1 were used to determine the influence of independent variables consisted of export, import, exchange rates, inflation rates, SBI, and foreign exchange reserves whereas the economic growth as the dependent variable. Normality Test also used in this study to understand the data characteristics with Jarque-Berra's test. It resulted that Jarque-Berra's rate was higher than X2 table with ( $\alpha 5$ percent) or the probability of $<0.05$. This means that the data used are normally distributed.

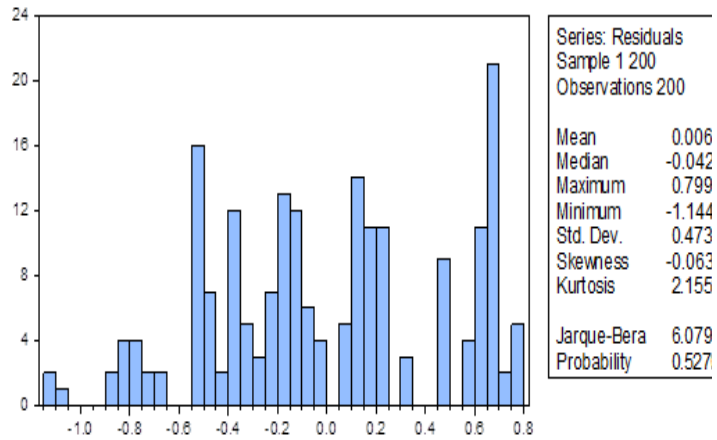

Figure 4(a). Normality Test Result

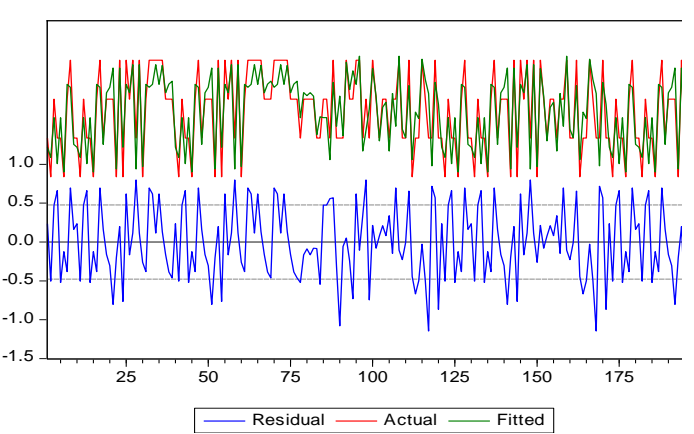

Figure 4(b) Heterosdascity Test Result

Source: Statistical analysis result (2016)

Normality test was referred as classical assumptions; therefore, OLS approach is suitable to be used in this study. In addition, the formed residual linear regression models were normally distributed to test the independent and dependent variables. It resulted the individual residuals are normally distributed, therefore, the author simply comparing the Jarque-Bera count with an alpha level of $0.05(5 \%)$. Since the Probability of Jarque-Bera count was equal to 0.527> 0.05 , therefore the residuals are normally distributed which means the classical assumption of normality were met.

From the F-test result, it can be explained that partially significant effect has been met especially among the relationship of tax amnesty SBI, inflation and the exchange rate to economic growth. Their relationship as evident by the t-test results can prove that the prices has less significance than real level of 0.05 or jointly as evidenced from $\mathrm{F}$ test as showed in table 1 below. 
Table 1. Regression Analysis

\begin{tabular}{lllll}
\hline Variable & Coefficient & Std. Error & t-Statistic & Prob. \\
\hline TAX AMNESTI & 0.641077 & 0.043069 & 14.88496 & 0.0000 \\
Exchange Rate & 0.077273 & 0.039532 & 1.954717 & 0.0420 \\
SBI & 0.220462 & 0.042784 & 5.152942 & 0.0000 \\
Inflation Rate & 0.082032 & 0.032777 & 2.502683 & 0.0131 \\
\hline R-squared & 0.776909 & Mean dependent var & 3.695000 \\
Adjusted R-squared & 0.773495 & S.D. dependent var & 1.003499 \\
S.E. of regression & 0.477591 & Akaike info criterion & 1.379672 \\
Sum squared resid & 44.70622 & Schwarz criterion & 1.445639 \\
Log likelihood & -133.9672 & Hannan-Quinn criter. & 1.406368 \\
Durbin-Watson stat & 2.097519 & & &
\end{tabular}

Source: Data Processed, 2016

The result of regression analysis showed that Tax Amnesty (X1) has positive effect on economic growth with a probability value of 0.0000 which smaller than $\alpha 0.05$. This pointed a relationship between tax amnesty with economic growth. It can be interpreted that the increase of tax amnesty will impact on higher economic growth. It is supported by Alm, J. (2012) that till the end of June, the concerns over the impact of Brexit policy to subside has brought global stock markets to be re-greening. In Indonesia, the official adoption of Act tax amnesty has successfully brought positive sentiment to better market stimulus and exchange stock market perspective. Investors' expectations to seek higher returns have encouraged inflows of funds from the UK to Asia where one of them is Indonesia after the referendum of Brexit. In addition, with the support of tax amnesty, it has been expected to increase the flow of funds. However, effectiveness of these policies will continue to be monitored over the next few months.

As exchange rate has positive influence on economic growth with a probability value of 0.042 , it has positive impact on the economic growth. The correlation has a direct effect which increases the economic growth. However, it is not supported by other evidence. The surprise result of the referendum of Brexit where British exit from the European Union has driven the Pound slumped and it also dragged the amount in the red zone due to the investor panic behavior. Therefore, the exchange rate must be based on the tendency to appreciate against potential diversion of investment.

Unlike England, the Indonesian currency has different stimulus from global market although the impact is felt in the stock market. However, the currency is expected to improve when the exchange rate has customized monetary policy since Indonesia is emerging market. This condition has been supported with the implementation of tax amnesty regulation per 1 July 2016. It brings positive effect which makes the regulation as a component of the monetary policy at which strengthens the currency in the months of July and August. Nevertheless, it is questioned in the long term that the movement will still be strongly influenced by external factors especially the effect of the global economy which not studied in this research. In addition, with the slowing down of China economy and the revision of the US growth figures after Trump administration 2016, it can bring slowdown and overshadow of the Rupiah Currency movement.

The table showed that the value of the rupiah against the US dollar in July 2016 were in the range of $\mathrm{Rp} \mathrm{13,400} \mathrm{-} \mathrm{Rp} \mathrm{13,600} \mathrm{and} \mathrm{at} \mathrm{the} \mathrm{end} \mathrm{of} \mathrm{October} 2016$ 
the currency has strengthened which around Rp 13.000- 13.200. It means that the purpose of the tax amnesty program for the improvement of the exchange rate has positive effect. In addition, the Capital markets Composite Stock Price Index also rose sharply through the level of 5000 by the end of June 2016. This represents an increase of investor confidence in the Indonesian stock market after the announcement of tax amnesty policy. This once again proved that the issue of the tax amnesty has already affected the investor perception that the economy of Indonesia will increase after many funds from repatriation entering Indonesia.

For SBI exchange rate, and based on the variable regression analysis result, it showed that SBI exchange rate (X3) has positive effect on economic growth with a probability value of 0.0000 which smaller than $\alpha$ count of 0.05 . In addition, it also found that the SBI exchange rate has increased the economic growth. It showed a correlation value between SBI exchanges in same direction of economic growth. It is reasonable since Bank Indonesia Certificates (SBI) is securities issued by Bank Indonesia in recognition of the bond with short time period (1-3 months) with a discount system/interest rate. SBI is one of the mechanisms used by Bank Indonesia to control the stability of the Rupiah. The selling of SBI can absorb excess primary currency distributed in the market. In Indonesia, the official adoption of tax amnesty act has successfully brought positive sentiment to the exchange rate as taxpayer converting their foreign money to Indonesian currency and increase the demand of Rupiah. It is evidence from the release of the trade balance which showing a surplus position but the value of exports and imports was down, so this is not a positive sentiment to the currency market. However, it is also found several times that the SBI exchange rate has increased $6.5 \%$ after the implementation of tax amnesty regulation.

Similarly, for the fourth variable, e.g., inflation, it found that the regression analysis has shown the inflation (X4) has positive effect on economic growth with a probability value of 0.031 . This value is smaller than $\alpha$ count of 0.05. It showed a positive relationship between inflation and economic growth. However, their devaluation policy in the short term may increase the inflation rate which following the economic growth.

\section{CONCLUSION}

Based on the analysis result above, it found several factors influencing conditions of macroeconomic in Indonesia. They can influence the growth of economy in Indonesia which primarily centered on the tax amnesty effects. These effects are distributed into the market and economy as below. After Indonesia implement free market system which leads to economic growth, Indonesia is very affected by the performance of international trade. It is evident in the regression analysis showed that the variable studied in this paper showed that the variables impacted on the economic growth. The regression analysis result showed that Tax Amnesty can impact the exchange rate since the increased flow of foreign fund from taxpayer. As the flow of foreign fund can increase the capital therefore, it is reasonable to accept that the tax amnesty policy can increase economic growth. For SBI exchange rate, it is also impacting the economic growth since it can strengthen the currency and also improve the government deposit of foreign money with higher interest rate. In addition, it is also influenced by the inflation as the indicator of economic growth. Tax Amnesty also has positive effect on 
economic growth in Indonesia. In more detail it explained that the repatriation fund from the taxpayer would affect the balance of payments which would then strengthen the exchange rate and finally reduce the input costs of production which bring better production quota with cheaper price. However, this effect does not studied widely. this is reasonable since the fund repatriation with various forms of foreign currencies especially US dollar can mobile the bank activities and improve the banking confidence of foreign currency and also the foreign trust toward the local currency of Rupiah. The implication, the rupiah demand will increase, and the economic growth will be in line with the strengthening of the rupiah after the implementation of tax amnesty policy.

\section{REFERENCES}

Bank Indonesia. (2016). Laporan Tahunan Bank Indonesia 2016. Retrieved from https://bi.go.id/.

BPS. (2016). Laporan Perekonomian Indonesia 2016. Jakarta: Badan Pusat Statistk.

Bird, R. M. (1989). The administrative dimension of tax reform in developing countries. Tax reform in developing countries, 315-346.

Bird, R. M., \& de Jantscher, M. C. (1992). Improving tax administration in developing countries (Vol. 19). Washington, DC: International Monetary Fund.

Chua, A. L. (1998). Markets, democracy, and ethnicity: toward a new paradigm for law and development. The Yale Law Journal, 108(1), 1-107.

Coale, A. J., \& Hoover, E. M. (2015). Population growth and economic development. Princeton University Press.

Costanza, R., de Groot, R., Sutton, P., van der Ploeg, S., Anderson, S. J., Kubiszewski, I., \& Turner, R. K. (2014). Changes in the global value of ecosystem services. Global Environmental Change, 26, 152-158.

Cypher, J. M., \& Dietz, J. L. (2008). The process of economic development. Routledge.

Chaney, T. (2016). Liquidity constrained exporters. Journal of Economic Dynamics and Control, 72, 141-154.

Dagan, T. (1999). Tax Treaties Myth, The. NYUJ Int'l L. \& Pol., 32, 939.

Di John, J. (2006). The political economy of taxation and tax reform in developing countries. United nations university. World institute for development economics research (UNU-WIDER).

Dodds, A. (2012). Comparative public policy. Palgrave Macmillan.

Engel, C. (2013). Exchange rates and interest parity (No. w19336). National Bureau of Economic Research.

Flood, R. P., \& Garber, P. M. (1984). Collapsing exchange-rate regimes: some linear examples. Journal of international Economics, 17(1), 1-13.

Gelfand, M. D. (1978). Seeking Local Government Financial Integrity Through Debt Ceilings, Tax Limitations, and Expenditure Limits: The New York City Fiscal Crisis, the Taxpayers' Revolt, and Beyond. Minn. L. Rev., 63, 545.

Gourinchas, P. O., \& Jeanne, O. (2013). Capital flows to developing countries: The allocation puzzle. The Review of Economic Studies, rdt004. 
Jackson, P. M., \& Smith, L. K. (2014). Exploring the undulating plateau: the future of global oil supply. Philosophical Transactions of the Royal Society of London A: Mathematical, Physical and Engineering Sciences, 372(2006), 20120491.

Korajczyk, R. A., \& Levy, A. (2003). Capital structure choice: macroeconomic conditions and financial constraints. Journal of financial economics, 68(1), 75-109.

Kouri, P. J. (1976). The exchange rate and the balance of payments in the short run and in the long run: A monetary approach. The Scandinavian Journal of Economics, 280-304.

Lefcoe, G. (2011). Competing for the next hundred million Americans: The uses and abuses of tax increment financing. The Urban Lawyer, 427-482.

Lewis, W. A. (2013). Theory of economic growth (Vol. 7). Routledge.

Smets, F. (2013). Financial stability and monetary policy: How closely interlinked?. Sveriges Riksbank Economic Review, 3, 121-160.

Steinmo, S. (1996). Taxation and democracy: Swedish, British, and American approaches to financing the modern state. Yale University Press. 